\title{
SOME LIMITED-INTEREST PROBLEMS
}

\author{
EDWARD S. GODFREY*
}

This paper discusses a few of the problems that arise out of an insured property loss where the policyholder's interest in the lost or damaged property, while sufficient to be insurable, amounts to less than full unencumbered ownership.

For example, suppose that $C$, one of two joint owners of a building, without any concealment or misrepresentation of the extent of his interest, obtains a fire policy insuring him against loss or damage to the property and pays premiums at the same rate that a sole owner would pay on the same property. The building burns. Is $C$ limited in recovery to one-half the value of the building at the time of the fire, or may he recover in the same manner as if he were sole owner of the fee? If he does recover, or is voluntarily paid, in excess of one-half the value of the building, does he hold the excess in trust for his co-owner? What happens if the other owner has also fully insured himself against loss to the same building?

Similar questions arise where the insured's interest is limited in other ways. Typically, disputes in this area of the law arise where the insured is a party to a bailment, land contract, mortgage, or lease. The property which is the subject of the insurance may be real or personal. The peril insured against may be fire or other hazard: although the law in this field has grown chiefly out of disputes arising under fire policies, the rules thus developed have been adopted where other types of nonmarine property insurance are involved. ${ }^{1}$ Of course, regardless of the type of peril covered, individual cases will be governed by specific policy language, especially valued policy clauses, and by applicable statutory provisions. ${ }^{2}$

We may frame our inquiry in general form as follows: assuming that a property loss has been sustained by a policyholder having a limited interest in the subject of the insurance; that the company cannot defend successfully upon any theory of misrepresentation, concealment, or breach of warranty or condition; ${ }^{3}$ and that there

- A.B. 1934, Harvard College; LL.B. 1939, Columbia University. Member of the New York bar; Professor of Law, Albany Law School, Union University since 1948 .

${ }^{2}$ Non-fire cases, not marine, involving limited-interest problems have been generally decided according to rules worked out in fire cases with little judicial comment upon that fact: Lack v. Western Loan \& Building Co., 134 F. 2d ror7 (gth Cir. 1943) (earthquake); Wohlt v. Farmers' Home Hail, Tornado \& Cyclone Ins. Co., 206 Wis. 35, 238 N. W. 809 (I93r) (tornado); Crisp County Lumber Co. v. Bridges, I 87 Ga. 484 , 200 S. E. 777 (1939) (storm).

? The effect of valued policy provisions will not be considered except incidentally. See Note, 68 A. L. R. 1344,1352 (1930).

"Litigation frequently arises under policies which are in terms "void" if the interest of the insured is not sole and unconditional ownership. (But see the $1943 \mathrm{New}$ York standard fire insurance policy in which this condition is eliminated.) Apart from statutory change, where the policyholder informs the company's agent of the limited nature of his interest at the time of placing the insurance, all but a few jurisdictions hold the company estopped to assert the breach of the sole-ownership condition. 
is no issue as to valuation of the loss apart from the question of measuring the insured's limited interest, ${ }^{4}$ then:

(I) What is the proper measure of recovery by the policyholder against the insurance company?

(2) If the company pays the policyholder the full amount of the loss, voluntarily or after suit, may other persons having interests in the property compel him to disgorge any part of his recovery?

(3) Where separate policies have been issued to the owners of other interests will multiple recovery against the companies insuring the several risks be permitted in an amount exceeding the total value of the property?

These and other related problems have already received considerable attention in the literature, ${ }^{6}$ and it is not here intended to offer anything like a full synthesis of the law on the subject. The peculiar rules in this branch of the law of insurance have been worked out mainly through and around two general ideas: the idea of indemnity, and the idea that a non-marine property insurance contract is a personal contract. $^{\top}$ Examination of the limited-interest cases over the past century reveals an interresting struggle in the courts over the scope and application of these juridical ideas. The insurers have sought in court to have "indemnity" defined narrowly and applied widely to limit recovery, and they have also sought to extend the doctrine that insurance is a personal contract so as to defeat recovery by or on behalf of any party to whom they have not clearly consented to be bound. ${ }^{8}$ On the other side, policyholders and other claimants have sought to expand the meaning of "indemnity" so as to prevent it from limiting recovery and have argued that the doctrine of non-assignability should be held to its original procedural confines. It is the purpose of this paper merely to show how the courts have resolved these opposed drives in a few types of cases and to indicate the bearing of recent decisions on the conflict.

This result is reached despite nonwaiver clauses. Welch v. Fire Ass'n of Philadelphia, 120 Wis, 456, 98 N. W. 227 (1904). Edwin W. Patterson, Cases and Materials on Insurance 7II (2d ed. 1947).

"The valuation problem has been treated by Bonbright and Katz, Valuation of Property to Measure Fire Itrsurance Losses, 29 CoL. L. REv. 857 (1929). See also Note, Valuation and Meastire of Recovery Under Fire Insurance Policies, 49 CoL. L. Rev. 818 (r949).

5 The problem of contributing insurance will not be considered. See George Richards, The Law op Insurance $45^{8-466}$ (4th ed. 1932). Nor subrogation problems. See George W. Goble, Cases on InsurANCE 709-726 (2d ed. 1949).

- See, e.g., 5 John A. Appleman, Insurance Law and Practice, cc. 149-I51 (1941); Goblc, op. cit. supra note 5, at 666-726; Patterson, op. cit. supra note 3, cc. 4-6, passim; Richnrds, op. cit. supra note 5, at 64-70, 75-84, 467-482; 2 Theodore Sedgwick, A Treatise on the Law of Dainges $1514-1518$ (gth ed. 1920); William R: Vance, Handbook of the Law of Insurance 652-666 (2d ed. 1930); William R. Vance, Cases and Other Materials on the Law of Insurance 659-689 (3d cd. i940); Harnett and Thornton, Insurable Interest in Property: $A$ Socio-Economic Reevaluation of a Legal Concept, 48 CoL. L. Rev. I162, II75-1178 (1948); Harvey, Insurance of Limited Interests-Mortgagor and Mortgagee, 10 L. Q. REv. 48 (1894); McClain, Insurance of Limited Interests Against Fire, 11 Hnsv. L. Rev. 512 (1898); Note, 68 A. L. R. I344 (1930). For a valuable discussion of the Canadian decisions, see Campbell, Some Aspects of Insurable Interest, 27 Can. B. Rev. I, 8 (1949).

${ }^{7}$ Lett v. G. F. Insurance Co., I25 N. Y. 82, 25 N. E. 1088 (1890).

${ }^{8}$ E.g., consent in advance would appear clearly implied in policies "for the benefit of whom it may concern." See PAtTERson, op. cit. supra, note 3 , at i78. 
When a modern court states that a contract of property insurance is a contract of indemnity, it usually has in mind some such proposition as this: that, unless otherwise agreed or required by statute, the recovery of the insured must be measured by the actual economic impairment of his interest in the insured res. ${ }^{9}$ Not less, for then the insured would not get as much as he bargained and paid for; not more, for then he might profit in some cases by occurrence of the insured event. The basic thought behind this proposition seems to be that the loss insured against is the loss in value of the insured's interest in the res, not necessarily the entire economic loss sustained by the insured as a result of damage to that interest. Loss of rents or profits, for example, is not recoverable under an owner's fire policy in the absence of specific coverage. $^{10}$ The insured's interest is thus conceived of as having an existence and value independent of its connection with the particular insured and independent of any special circumstances in which he may find himself. The amount of the loss is to be objectively evaluated accordingly. ${ }^{11}$

Emlin McClain has shown how the notion of indemnity, at first used chiefly as a test for distinguishing insurance policies from wagering contracts, developed into a norm for ascertaining the proper measurement of recovery. ${ }^{12} \mathrm{McClain}$ 's conclusion from examining the early limited-interest cases was: ${ }^{13}$

Although these illustrations indicate that a description of insurance as a contract of indemnity did not mean all that such a statement has, in the later development of the law, been supposed to mean, yet they may perhaps be considered as indicating a general conception of the obligation of the insurer, limiting it in practice, so far as consistent with the express language employed, to an obligation to make good the loss suffered by the insured through the destruction of or injury to the property within the terms of the contract. Judges have frequently qualified the expression as to indemnity by saying that the contract is not a perfect contract of indemnity, but the disposition has been very strong to reason out every question arising as to the liability of the insurer on the theory that indemnity only has been contracted for.

By the time McClain made his study, several peculiar applications of the indemnity principle had become well recognized. Thus, it was already settled that the mortgagee or the vendor who insures his own interest in real estate against fire is not limited in recovery to the extent to which his security is impaired below

${ }^{\circ}$ Cf. I John W. MAY, LAw of INsuranteE $\$ 6$ (4th ed. Igoo); Harnett and Thornton, supra note 6, at $\operatorname{Ir} 76$.

${ }^{10}$ Vance, HandBook of the Law of Insurance 932 (2d ed. 1930). See Bonbright and Katz, supra note 4 , at 865 .

11 The courts tend to think of "value" itself as something "more or less intrinsic and objective." Bonbright and Katz, supra note 4 , at $864-866$.

${ }^{12}$ McClain, supra note 6 , at 512-515.

${ }^{23} \mathrm{Id}$. at 515 . (Footnotes omitted.) This formulation of the doctrine of indemnity is somewhat different from that suggested in the text, stipra. Applied literally, McClain's proposition seems to exclude recovery by a mortgagee who has insured his own interest and whose security remains ample despite the damage to the premises. The decisions do not support such an exclusion, as McClain observes. "Id. at 517. On the other hand, his formulation would permit recovery of renis contrary to the decisions. 
the amount of his outstanding claim against the mortgagor or vendee. ${ }^{14}$ Such socured creditors insuring their own interest are held entitled to the amount of the loss to the property itself, limited only by the face amount of the policy and the amount of the outstanding debt. In brief, the company is not permitted to show that the mortgagee or vendor is not really damaged because the remaining security is ample, the courts emphasizing that the subject matter of the insurance is "the property," not the debt. ${ }^{15}$ However, in these cases "the property" turns out to be only the insured's interest in the property, since all courts do limit the secured creditor's recovery to the amount of his outstanding claim $^{16}$ where no agency or trust can be found to sustain recovery of an additional sum for the benefit of the debtor. ${ }^{17}$ The net effect is that the non-risk-bearing mortgagee or vendor who insures his own interest recovers for his own use and benefit either the policy limit, or the amount of the outstanding debt, or the amount of the loss or damage to the property as a whole, whichever is least.

In all this there is no serious strain on the classical theory of indemnity. In fact, these security cases strongly support the view that the loss or damage for which the insured will be "indemnified" is the loss or damage sustained by his interest in the res conceived as having independent existence and value-not necessarily the economic loss actually sustained by the insured himself as a result of the disaster, nor yet necessarily the full loss in value sustained by the res.

The bailment cases create little difficulty so far as the theory of indemnity is concerned. The bailee purporting to insure against loss to property held "in trust or on commission, or sold but not removed," is permitted to recover the full amount of the loss within the policy limit even though he is under no liability for loss of the goods, has no lien for charges, and has not even adduced positive evidence of ratification or adoption of the policy by the bailor either before or after the loss. ${ }^{18}$ An original intent to benefit some bailor is presumed. Ratification or adoption of the policy is also presumed. Consequently, to the extent that recovery under the policy would

${ }^{14}$ Excelsior Fire Insurance Co. v. R. Ins. Co. of Liverpool, 55 N. Y. 343, 355 (I873) (mortgagee); Wohlt v. Farmers' Home Hail, Tornado \& Cyclone Insurance Co., 206 Wis. 35, 238 N. W. 809 (193I) (vendor). The same principle has been applied to the insurance of a mechanics' lien. Royal Insurance Co. v. Stinson, 103 U. S. 25 (188r). See Note, 68 A. L. R. 1344, 1350 (1930).

${ }^{15}$ Excelsior Fire Insurance Co. v. R. Ins. Co. of Liverpool, stipra note $\mathrm{x} 4$. This result has been reached even where the mortgagee has collected the entire amount of the debt upon foreclosure after the loss. Sun Insurance Office v. Beneke, -53 S. W. 98 (Tex. Civ. App. 1899). Likewise, where the mortgagor-owner has restored the damaged premises, without the knowledge or consent of the mortgagee, before the loss became payable. Savarese v. Ohio Farmers Ins. Co., 260 N. Y. 45, 182 N. E. 665 (1932). As to whether procuring of insurance by the mortgagee violates a provision in mortgagor's policy against additional insurance, see Note, 66 A. L. R. r173 (1930).

${ }^{26}$ This proposition does not hold in the relatively rare case where the mortgagee or vendor bears the risk of loss in the transaction.

${ }^{17}$ Smith v. Hardware Dealers Mut. Fire Ins. Co., 253 Wis. 129, 33 N. W. $2 d 206$ (1948). See note I6 supra.

${ }^{18}$ Waring v. The Indemnity Fire Ins. Co., 45 N. Y. 606, 6 Am. Rep. 146 (187r). 
exceed the amount of loss to the bailee's own interest in the goods, he holds the proceeds for the use and benefit of the owner of the goods. ${ }^{19}$ Moreover, the bailor is permitted to recover on the bailee's policy if the bailee declines to do so. ${ }^{20}$

The device of implying an agency or trust has attracted the courts in other divided interest cases where they have wished to prevent both the escape of the insurer and the undesirable enrichment of the insured. Thus, despite English precedent to the contrary, ${ }^{21}$ the majority of American courts have permitted the contract vendee of real estate who bears the risk of loss to recover insurance proceeds paid to the vendor where covered loss or damage to the premises occurred before conveyance of the title. ${ }^{22}$ Usually, where this result is reached, the vendor has placed the insurance some time prior to the making of the land contract. ${ }^{23}$ The vendor is said to be trustee of the proceeds to the extent that they exceed the vendee's outstanding obligation for the purchase price, although the vendor has made no express agreement to insure for the vendee's benefit. ${ }^{24}$

The problem of the courts in the land contract cases has been not so much how to apply the indemnity principle as how to justify recovery by or for the vendee in the face of the traditional rule against assignability of non-marine property insurance. Whatever the procedural origin of the doctrine that non-marine property insurance is a personal contract, ${ }^{25}$ it has undoubtedly been fostered by the reluctance of the courts to subject insurance companies to liability to strangers of unknown honesty on contracts where there is often strong temptation to fraud. The bailment cases probably did not originally, and certainly do not now, represent a breach of this rule, since consent in advance on the part of the company to recovery by or for the bailorowner is reasonably inferred from the known needs of commerce. ${ }^{26}$ However, in the land contract cases, the circumstances are not so helpful in supporting the inference of consent in advance. The moral hazard seems clearly greater, in fact, in the case of the risk-bearing vendee in possession of realty than in the case of the bailorowner of goods who is out of possession. But the courts are faced with a trilemma: they must either ( $x$ ) let the company escape liability so far as the vendee's interest

\footnotetext{
${ }^{10}$ The precise language of the policy must be watched. Where the policy covered bailee's "interest in and legal liability for" property held by bailee "in trust or on commission or on joint account with others or on storage or for repairs," it was held that the bailor-owner's interest had not been covered. Brooklyn Clothing Corp. v. Fidelity-Phenix Fire Ins. Co., 205 App. Div. 743, 200 N. Y. Supp. 208 (2d Dep't 1923).

${ }^{20}$ Exton \& Co. v. Home Fire \& Marine Ins. Co., 249 N. Y. 258 , I64 N. E. 43 (r928); Kellner v. Fire Association of Philadelphia, r28 Wis. 233, 106 N. W. 1060, II6 Am. St. Rep. 45 (1906).

${ }^{21}$ Rayner v. Preston, 18 Ch.D. I (I88I).

${ }^{22}$ E.g., Brady v. Welsh, 200 Iowa 44, 204 N. W. 235 (1925). But see Brownell v. Board of Education, 239 N. Y. 369, 374, 146 N. E. 630, 63I (1925). See Notes, 37 A. L. R. 1324 (I925), 40 A. L. R. 607 (1926), 5I A. L. R. 929 (I927). Where risk of loss is on the vendor before conveyance, the vendee has been held not entitled to specific performance with application of vendor's insurance money to the purchase price. Brownell v. Board of Education, stipra. See Pepper, The Rights of Vendor and Vendee in Respect of a Policy of Insurance Upon Property Sold, 33 AM. L. Reg. 134 (1894).

${ }^{29}$ But in Godfrey v. Alcorn, $215 \mathrm{Ky} .465,284 \mathrm{~S}$. W. 1094 (1926), the vendor insured his own interest after the contract had been made.

24 Brady v. Welsh, supra note $22 . \quad 26$ See Patterson, op. cit. supra note 3, at I81.

${ }^{26}$ See Waring v. The Indemnity Fire Ins. Co., 45 N. Y. 606, 6 Am. Rep. 146 (r87r).
} 
is concerned, after it has collected premiums for coverage of the very premises injured; or (2) let the vendor recover the entire insurance for his own sole benefit when his interest in the property is limited to a vendor's lien, thus violating the indemnity principle; or (3) let the vendee recover against the company or against the vendor on the fiction of a trust, thus actually, though not openly, violating the personal-contract principle. ${ }^{2 \pi}$ Presented with these alternatives, the courts have generally chosen the third, sometimes in the teeth of policy language strongly indicating that the insurer would have declined in advance to become liable for any loss or damage to a vendee's interest. ${ }^{28}$ Justification for this choice has been found in the equitable rights and duties that spring out of the land contract. The prevailing attitude is as stated in the opinion adopted by the Supreme Court of Pennsylvania in Reed v. Lukens: $:^{29}$

... the plaintiff [vendee] was still obliged to take the property and pay the purchase money. The insurance company, however, became liable to pay for the loss to the defendant [vendor], because ... he, as respects third parties, not privy to the contract of sale, is still to be regarded as the owner of the property. But as between himself and the plaintiff, the property was not his, but the plaintiff's; he could not appropriate to himself the money which the insurance company became liable to pay on that account; he had the property in trust, and the right which accrued in consequence of its destruction, took its place, was held in the same way, and liable to be enforced in a court of equity.

With this attitude prevalent, it is improbable that the clause contained in some form in every standard fire policy, purporting to invalidate an assignment of the policy, or to invalidate the policy itself upon assignment, without consent of the company, will of its own virtue save the company from liability for an amount including the vendee's interest, at least where the policy itself has not been assigned. In Dubin Paper Co. v. Insurance Co. of North America, ${ }^{30}$ the Supreme Court of Pennsylvania permitted a vendee who had paid the full purchase price to prevail in a bill in equity to compel the insurers (I) to pay the proceeds of two fire policies to the representatives of the insured vendor and (2) to compel those representatives to hold the proceeds as trustees for the plaintiff. One of the policies involved was "substantially in accord" with the rg2r Pennsylvania standard fire policy, which contained a clause purporting to avoid the policy if assigned before loss. ${ }^{31}$ The limiting words of the 1943 New York standard fire policy, ". . . nor in any event for more than the interest of the insured ..." pose a nice problem in this type of case

\footnotetext{
${ }^{27}$ Similar alternatives are discussed in Note, Subrogation of the Instrer to Collateral Rights of the Instured, 28 CoL. L. Rev. 202, 203 (1928).

${ }^{28}$ Dubin Paper Co. v. Insurance Co. of North America, 36r Pa. 68, 63 A. 2d 85 (1949). One of "the policies involved contained a provision: ". . . nor shall the interest of the vendec or any other parties to the Agreement of Sale except the Assured hereunder be insured by this policy." "The vendec prevailed in a bill in equity against the insurer and the vendor. This result is basically hard to reconcile with cases like Ritson v. Atlas Assurance Co., 272 Mass. 73, 171 N. E. 448 (1930), denying an undisclosed principal the right to sue on the policy even where he was a co-owner of the property with the agent who was nominally insured.

${ }^{28} 44 \mathrm{~Pa} .200,202,84$ Am. Dec. 425, 427 (1863).

${ }_{30} 6 \mathrm{r}$ Pa. 68,63 A. $2 d 85$ (1949).

${ }^{31} I d$. at 86,63 A. $2 d$ at 94, n. 5 .
} 
which apparently has yet to be decided. If the reasoning and language of the Dubin case were followed, a vendee's interest might still be included by representation in the vendor's recovery even in a jurisdiction using the 1943 New York policy. ${ }^{32}$ A strict construction of this language of the policy would eliminate any recovery on behalf of a represented interest. The courts may choose to say that such a sweeping change could not have been intended by the legislature, and thus permit recovery under the old rules where represented interests are involved.

The equitable duties of the vendor of land have thus been the basis for the finding of a fiduciary relationship between vendor and vendee, enabling the majority of courts to hold the insurer fully liable and, at the same time, avoid enrichment of the vendor as a result of the loss. In such a view of the matter, there is no basis for subrogation by the insurer to the vendor's contract claim against the vendee. ${ }^{33}$

\section{III}

A different situation is presented where insurance is taken out by a mortgagee or mortgagor. Here, neither party is entitled to any part of the proceeds of the other's insurance, ${ }^{34}$ unless ( $I$ ) there can be found some agreement by the policyholder to insure for the benefit of the other party, so that an equitable lien may be imposed upon the proceeds, ${ }^{35}$ or (2) the policy itself contains language, such as an open or union mortgage clause, upon which a right in the other party may be founded. In the absence of some express manifestation of consent, the courts have found no basis for inferring a fiduciary relationship between mortgagor and mortgagee in this connection. ${ }^{36}$

The mortgage cases are also perfectly consistent with the strict idea of indemnity. The mortgagee's recovery under his policy for his own benefit is limited as stated earlier in this article. Under a policy taken out for his own sole benefit, the mortgagor-owner recovers the entire amount of the loss within the policy limit, a result which is easily sustainable on the ground that he remains liable upon the mortgage debt after the premises have been destroyed or damaged and bears the risk of loss. ${ }^{37}$ These rules obtain even where both parties have insured their interests separately. ${ }^{38}$

${ }^{32}$ Ibid. See Patterson, Insurance Law During the War Years, 46 CoL. L. Rev. 345, 354 (I946).

${ }^{33}$ See Note, Subrogation of the Insurer to the Collateral Rights of the Insured, 28 CoI. L. REv. 202, 204 (I928).

s'Farmers' Loan \& T. Co. v. Penn Plate Glass Co., 186 U. S. 434 (xg02); Carpenter v. The Provident Washington Insurance Company, r6 Pet. 495 (U. S. 1842). 5 Applemsan, op. cit. supra note 6, \$381: Harvey, supra note 6, passim. Sce also Note, The Standard Mortgagee Clatise in Fire Instrance Policier, 33 CoL. L. Rev. 305 (1933).

s5 Chipman v. Carroll, 53 Kan. 163, 35 Pac. r rog (1894).

${ }^{38}$ See note 34 supra.

${ }^{37}$ Royal Ins. Co. v. Stinson, I03 U. S. 25 (188r). See Note, 68 A. L. R. 1344, I350 (1930)". Cf. Harvey, supra note 6, at 48 : "It would be otherwise if the debt were discharged by the loss of the security, as in the case of a loan upon a bottomry or respondentia bond. In these loans the risk .... is upon the lender, and not on the owner, who can, therefore, recover . . . the excess only of the value of the security over the amount of the advance."

${ }^{38}$ Farmers' Union Mut. P. Ass'n v. San Luis State Bank, 86 Colo. 293, 281 Pac. 366 (r929); Brant v. Dixic Fire Ins. Co. of Greensboro, N. C., I79 S. C. 55, I83 S. E. 587 (I935). 
To prevent enrichment of either mortgagor or mortgagee, where a mortgagee has insured for his own sole benefit his insurer will be subrogated pro tanto to the mortgage debt after paying the mortgagee on his policy. ${ }^{39}$ Again, in permitting full recovery by a mortgagor-owner, the courts have insisted that what is being measured is the loss sustained by the insured's property interest itself, not necessarily the loss actually sustained by the insured, who may have defaulted on his bond and whose affairs may be so embarrassed that redemption is, in fact, quite improbable. ${ }^{40}$ The insured's property interest is thought of as still amounting to ownership of the res although events have made its early defeasance almost certain. ${ }^{41}$

\section{IV}

There have been relatively few decisions on the proper measure of recovery by a policyholder whose interest in the res is that of either common or joint ownership. ${ }^{42}$ Under the old standard fire policy forms, the sole and unconditional ownership clause usually defeated such a policyholder at the outset. ${ }^{43}$.

In the absence of circumstances raising an inference of agency or trust for the other cotenants, where one owner in common has insured the common property for its full value, recovery by the insured against the company has usually been limited to the value of his share. ${ }^{44}$ Inference of agency or trust has not been drawn merely from the fact that the insurance was placed upon the property at its full value. ${ }^{45}$ Even where other cotenants were infants closely related to the insured, the insured tenant in common has been limited in his recovery. ${ }^{46}$ Consistently with this view, the insured tenant in common has been held to have no duty, arising merely out of the cotenancy relationship, to share insurance proceeds with the other cotenants

${ }^{30}$ Leyden v. Lawrence, 78 N. J. Eq. 453, 79 Atl. 6r5 (I9Ix), same case 79 N. J. Eq. 113, 81 Atl. 121 (I9II), affirmed 85 Adl. II34 (N. J. I9I2). See Richards, supra note 5, at 79; Harvey, stipra note 6 , at 52 .

${ }^{40}$ Farmers' Union Mut. P. Ass'n v. San Luis State Bank, 86 Colo. 293, $28 x$ Pac. 366 (1929). C/. Columbian Insurance Company v. Lawrence, 2 Pet. 25,46 (U. S. 1829 ) (vendee of realty in possession under a contract subject to an unfulfilled condition).

4I In Perkins v. Century Ins. Co., 303 Mich. 679, 7 N. W. $2 \mathrm{~d}$ 106 (1942), the insured owner of the equity of redemption was held to be entitled to more than nominal recovery against the company although the loss occurred on the last day of the existence of her right to redeem.

${ }^{42}$ The authorities have not been carcful to distinguish between joint tenancy and tenancy in common in connection with this subject.

${ }^{43}$ Porobenski v. American Alliance Ins. Co. of New York, 317 Pa. 410, 176 Atl. 205 (1935) (tenants by the entirety). The r $943 \mathrm{New}$ York standard fire policy omits this clause.

${ }^{14}$ Knight v. Eureka Fire \& Marine Ins. Co., 26 Ohio St. 664, 20 Am. Rep. 778 (1875); Summer v. Stark County Patrons' Mut. Ins. Co., 63 Ohio App. 369,26 N. E. 2d 1021 (1940). But sec National Union Fire Ins. Co. v. Morgan, 23I Ala. 640, I66 So. 24 (1936) (insurer linew the facts and collected full premium).

${ }^{15}$ In Burrows v. Farmers' Alliance Ins. Co., III Kan. 358, 207 Pac. 431 (1922) on rehearing, insured was not permitted recovery beyond the amount of his own loss although insurer's agent kncw of the limitation on insured's interest at the time of application. Plaintiff was denied recovery on behalf of the other co-owners because of a deficiency in his pleading. But see National Union Fire Ins. Co. v. Morgan, 231 Ala. 640, r66 So. 24 (r936), permitting full recovery where the insurer knew of the limitation on the insured's interest and with that knowledge issued a policy as for an absolute title and received full premiums.

${ }^{10}$ American Ins. Co. v. Porter, 25 Ala. App. 250, 144 So. 129 (1932). 
whether or not the proceeds represent substantially the full value of the res. ${ }^{47}$ As might be expected, a tenant in common who did not insure the property has no cause of action against the policyholder's company. ${ }^{48}$

Greater difficulty is presented by the measurement of a joint tenant's recovery where he has insured for his own sole benefit. Since a joint tenant owns the whole estate for some purposes in the law, the courts might on that ground conceivably refuse to limit his recovery to the value of a fractional share of the estate. On the other hand, without the limitation the danger is present of separate recoveries by several joint tenants upon different policies in a sum total exceeding the amount of the loss. A similar situation, resulting in recoveries probably totaling in excess of the amount of the loss, was involved in a recent case in the Texas Court of Civil Appeals, although there the interest of the insured was more nearly that of a partner than joint tenant. ${ }^{49}$ The opinion seems to rest chiefly upon the presence of a valued policy statute and upon the insurer's knowledge of the existence and amount of the other insurance on the premises. No case has been found actually passing upon the measure of recovery against the insurer by a joint tenant, as distinguished from a tenant in common. There has been some dictum indicating that the insured's recovery would be limited. ${ }^{50}$ The rights of other joint tenants to share in proceeds recovered by an insured joint tenant are governed by the same considerations that apply in the case of tenants in common. ${ }^{51}$ It has been said that "whether the other joint owner has an interest in law or equity in the insurance money so collected may properly turn on the equities of the particular case." ${ }^{32}$

\section{$\mathrm{V}$}

Life tenants, lessees for years, and tenants with various insecure tenures such as estates at will or at sufferance or by the curtesy initiate, have made much trouble

${ }^{47}$ Collette v. Long, 179 Miss. 650, 176 So. 528 (1937); Annely v. De Saussure, 26 S. C. 497,2 S. E. $490(1887)$.

${ }^{4}$ Continental Ins. Co. v. Maxwell, 9 Kan. App. 268, 60 Pac. 539 (1900). Even where the insured intended to act as agent for the co-owner as undisclosed principal, the co-owner was denied the right to sue in Ritson v. Atlas Assurance Co., 272 Mass. 73, I7I N. E. 448 (r930). But see Howard Ins. Co. v. Chase, 5 Wall. 509 (U. S. 1867). The named insured in the Ritson case was said to be entitled to recover up to the value of his own interest, but no statement was made of what that would be. As to whether breach of condition by one tenant in common bars recovery by innocent co-tenants, sce Note, $1_{4} 8$ A. L. R. 487 (1944).

"American Cent. Ins. Co. v. Harrison, 205 S. W. 2d 417 (Tex. Civ. App. 1947). The Court of Civil Appeals permitted full recovery by a co-tenant in London Assur. Corporation v. Belcher, 5 S. W. $2 d$ 844 (Tex. Civ. App. 1928), where the insurer knew that insured was only a part owner at the time of issuing the policy. In that case also, excess recovery by two co-owners was the result.

${ }^{80}$ Miles v. Miles, 211 Ala. 26, 29, 99 So. 187, 190 (1924).

${ }^{41}$ Miles v. Miles, 2 I I Ala. 26, 99 So. I87 (I924) (denying recorery by husband against wife who had maintained insurance on joint property). See 5 Appleman, op. cit. supra note $6, \S 336 \mathrm{r}$; $46 \mathrm{C}$. J. S. EII 4 I (I946).

${ }^{82}$ Miles v. Miles, supra note $5 \mathrm{I}$, at 29,99 So. at 590 . In a jurisdiction enforcing oral partitions among joint or common owners, it seems that in any case where such a partition has set off the subject of the insurance entirely to one co-tenant, such co-tenant should be entitled to full recovery for the loss within the policy limit, he being deemed in equity the sole owner of the land. See 2 WARREN F. WALSH, Commentaries on the Law of Real. Property 80 (3d ed. i947). 
for the courts in this field, and the cases involving such persons show less uniformity in their results than those so far discussed. In fact, the strict theory of indemnity has been openly disregarded in some of the opinions in these cases. ${ }^{\text {b3 }}$

There ought to be little question that such a tenant who actually intends and purports to insure only his own interest in the property should recover only the value of that interest, which should be measured by the difference between the reasonable rental value and the rental cost to the insured for the probable remainder of the term, to be computed from material evidence, including life tables if necessary. ${ }^{54}$ Such a result does not conflict with the rule that ordinarily the insured is not entitled to loss of use or rents under a fire policy; computation of the total prospective reasonable rental is merely a reasonable mode under the circumstances of determining the "intrinsic value" of the life estate. It must be said, however, that there are some cases which, while distinguishable, support the conclusion that the life tenant purporting to cover only his own interest may yet recover for the full loss to the entire res within the policy limit. ${ }^{55}$ This view can be traced back at least as far as Franklin Ins. Company v. Drake. ${ }^{58}$ There the insured, whose wife owned a two-fifths undivided equitable interest in certain houses, "effected an insurance of his two-fifths in said houses." The insured's own interest in the premises was only a right to their use and enjoyment or their rents during the joint lives of himself and his wife, and a prospective statutory tenancy by the curtesy after the death of the wife. The court, finding that the husband intended to insure the full two-fifths interest in the houses, permitted recovery of the full value of the two-fifths interest within the limit of the policy. There was no intimation that the husband might have acted as agent for his wife in insuring the property. Instead the court used the following broad language to justify full recovery: ${ }^{57}$

If the assured had an insurable interest at the time of the insurance and also at the time of loss, he has a right to recover the whole amount of damage to the property, not exceeding the sum insured, without regard to the value of the assured's interest in the property.

The court cited mortgage cases, which support no such broad proposition, and the hypothetical case of a lessee for years whose lease is about to expire but who is said to be none the less entitled to recover the full value of the property destroyed within the policy limit. The modern cases are divided on the latter proposition with probably some preponderance of authority against it. ${ }^{68}$ It seems that the

${ }^{s s}$ Western Assur. Co. v. Stoddard, 88 Ala. 606, 7 So. 379 (1889); Merrett v. Farmers' Insurance Co., 42 Iowa II (1875); The Franklin Marine and Fire Ins. Co. v. J. G. Drake, 4 I Ky. (2 B. Mon.) 47 (184I). Cf. Harnett and Thornton, stpra note 6, at 1176 .

${ }^{54}$ Getchell v. Mercantile \& Mfrs. Mut. Fire Ins. Co., I09 Me. 274, 83 Atl. 801 (1912); Note, 42

L. R. A. (N. s.) I35 (1913). But see Harnett and Thornton, supra note 6, at 1176.

${ }^{65}$ See Liverpool \& London \& Globe Ins. Co., Ltd. v. Bolling, 176 Va. 182, Io S. E. 2 d 518 (1940).

so $4 \mathrm{I} \mathrm{Ky.} \mathrm{(} 2$ B. Mon.) 47 ( $1.84 \mathrm{I}$ ).

67. Id. at 50 .

${ }^{58}$ Hale v. Simmons, 200 Ark. 556, 139 S. W. 2d 696 (1940); Harrington v. Agricultural Ins. Co., 179 Minn. 5,10, 229 N. W. 792 (1930). See also Citizens' Fire Ins. Co. v. Lockridge, 132 Ky. 1, 5, 116 
Kentucky court would have been on safer ground to find a fiduciary relation between the insured and his wife and sustain recovery on that basis rather than completely disregard the principle of indemnity. However, the decision has had a pervasive influence in subsequent cases where the rights of life tenants and lessees have been concerned. 59

Where a life tenant has insured the property up to its full value with the manifest intent of benefiting the remainderman or reversioner as well as himself, there has been little difficulty in sustaining full recovery. ${ }^{60}$ In that event the insured holds the proceeds in trust for the remainderman to the extent that they exceed the value of his own interest. ${ }^{61}$

The cases in which the life tenant has insured up to full value for his own sole benefit are divided as to the measure of recovery against the company. Here, generally speaking, the courts have not been attracted by any theory of agency or trust. $^{62}$ An old Illinois case permitted the life tenant full recovery in this situation, relying upon the supposed principle announced in the Drake case, ${ }^{63}$ and in 1875 the Supreme Court of Iowa took the ground that a smaller sum would not compensate the insured life tenant for the loss sustained. ${ }^{64}$ This latter argument is said to be especially forceful where the insured occupied the premises as a homestead. ${ }^{65}$ Actually it proceeds from the premise that the insurer has agreed to indemnify the insured for all loss he sustains as a result of the insured event. Such is not the contract in most of these cases. Reasoning which allows full recovery to the life tenant merely because of loss of use and occupancy cannot be reconciled with reasoning which denies recovery for use and occupancy by an owner under an ordinary fire policy. ${ }^{60}$

Opposed to the Illinois and Iowa decisions referred to are two cases applying the strict principle of indemnity and limiting the life tenant's recovery to the estimated value of his interest. In Beekman v. Fulton \& M. Counties F. M. Fire Ins. Ass'n, ${ }^{67}$ a life tenant, fully insuring the premises solely for his own benefit, was limited in recovery to the value of his right of use for life, to be determined upon evidence of the locality and surroundings. The Appellate Division seemed to approve the

S. W. 303, 304 (rgo9). Contra: Mississippi Fire Ins. Co. v. Planters' Bank. 138 Miss. 275, 103 So. 84 (I925) (under valued policy statute); Mancini v. Yorkshire Ins. Co., Ltd., of York, England, 54 R. I. 79 , 170 Atl. 82 (1934). See Patterson, op. cit. supra note 3, at 280.

${ }^{\circ 0}$ See Merrett v. Farmers' Insurance Co., 42 Iowa II (1875).

${ }^{\circ 0}$ Convis v. Citizens' Mut. F. Ins. Co., I27 Mich. 616, 86 N. W. 994 (rgor); Trade Ins. Company v. Barracliff, 45 N. J. L. 543 (I883). For the problems involved where a testator insured the property, see Note, 2 I Col. L. Rev. 49I (I92r).

${ }^{\circ}$ Convis v. Citizens' Mut. F. Ins. Co., supra note 6o; Note, 126 A. L. R. 336, 349 (1940).

${ }^{02}$ See In re Gorman's Estate, 32x Pa. 292, 184 Atl. 86 (1936).

${ }^{03}$ Andes Ins. Co. v. Fish, $7 x$ Ill. 620, 625 (1874).

- Merrett v. Farmers' Insurance Co., 42 Iowa II (1875).

${ }^{\circ 5} \mathrm{McClain}$, supra note 6 , at 518 , quoting from the opinion of Bowen, L. J., in Castellain v. Preston, 11 Q. B. D. 380,400 (I883), where support may be found for almost any position in the law of fire insurance.

${ }^{\circ 0} \mathrm{Cf}$. Harnett and Thornton, supra note $6,1176, \mathrm{n} .85$.

${ }^{07} 66$ App. Div. 72, 73 N. Y. Supp. I10 (3d Dep't 1901). 
use of mortality tables for measuring the life of the plaintiff, but rejected the company's contention that the value of the annual use of the house to the insured should be computed automatically at five per centum of the cash value of the house in accordance with the New York rule for computing the present value of life estates. In the Beekman case, the company seems not to have been aware of the limitation on the insured's interest at the time the policy was issued.

The following year, the Massachusetts high court, hewing to the line of strict indemnity, held that a tenant by the curtesy initiate who purported to insure fully his wife's property for his own benefit must be limited in recovery to the value of his inchoate right at the time of the loss. ${ }^{68}$ In the court's view, longevity was to be determined primarily by life tables, but actual probabilities might be shown by testimony. The court remarked upon the difficulty of assessing damages in such a case.

These cases arise out of a situation that seems to be rather common, in which a man thoughtlessly insures his wife's property in his own name. Considering the large number of property insurance transactions and the fact that they are seldom entered into with advice of counsel, the frequency of the error is not surprising. In some cases the agent of the company is aware of the true state of the title; in others, not. If the company refuses to pay the loss, the insured upon suit is confronted with the defenses of misrepresentation or non-disclosure and want of insurable interest. If the company knew the state of the title when it issued the policy, or if the insured made no actual misstatement about it, the policyholder usually succeeds in overcoming the first defense with the weapon of estoppel. But in jurisdictions which give the husband no possessory rights in his wife's land the defense of insurable interest has often barred recovery. ${ }^{69}$ We are thus considering here the fate of that remnant of insureds who have surmounted those absolute defenses, and the question is whether their recovery should be limited by strict application of the doctrine of indemnity and the doctrine that insurance is a personal contract.

One basic argument for the doctrine of indemnity in fire insurance, that the incentive to incendiarism should be reduced as much as possible, lacks force when it is sought to be applied in this particular type of case. Normally, the marital relationship is close enough and the practical interests of both spouses are so nearly identical that there is no more incentive for the husband to burn his wife's property than there is for her to burn her own, especially where the insured res is a building which both spouses are occupying as a homestead. Perhaps somewhat more forceful in this situation is the argument that the insurer should have the privilege of passing upon the character of those for whose losses it may become liable. Still, the purpose of the privilege is to enable the company to reject undesired moral risks, and the actual difference in quantum of moral risk assumed by insuring the non-owning, rather than

\footnotetext{
${ }^{88}$ Doyle v. American Fire Ins. Co., I81 Mass. 139, 63 N. E. 394 (1902).

${ }^{\circ 0}$ Bassett v. Farmers' and Merchants' Ins. Co., 85 Neb. 85,122 N. W. 703 (rgog); Note, 68 A. L. R. 362 (r930).
} 
the owning, spouse is normally very slight. Normally also, insurance by the nonowning spouse is not taken out with any intent to make a wagering contract. If it appears that the owning spouse has not insured the res, that fact is a circumstance tending to show that the policy taken out by the other spouse was not actually a wager.

For these reasons the courts have not been too sympathetic with efforts by some insurers to limit recovery in these cases when there has been no intentional deception, wagering, or other misbehavior on the part of the insured or his spouse, and where the company has collected premiums at the full rate. ${ }^{70}$ The difficulty has been in finding a sound legal basis for permitting full recovery. A number of techniques have been employed. Some courts have implied an agency in the husband to insure on behalf of his wife. ${ }^{71}$ This device saves the indemnity principle but runs afoul of the personal-contract doctrine, which bars recovery by an undisclosed principal on a contract of insurance made by his agent. ${ }^{72}$ A number of courts, following the dictum of the Drake case, supra, and a pronouncement in Corpus Juris, ${ }^{73}$ have taken the position in these and other cases that if the insured had an insurable interest at the time of the loss, he is entitled to recover the full amount of the loss within the policy limit, regardless of the extent of his particular interest. ${ }^{74}$ As a general principle, this proposition seems manifestly unsound, ${ }^{\mathbf{7 5}}$ but it has proved useful in the type of case under discussion.

Reformation does not seem to be helpful. There is clearly no basis for reformation if the company was unaware of the true state of the title at the time of issuing the policy. ${ }^{\text {70 }}$ Even if the company knew the facts at the time of issuing the policy it will still be impossible in most cases to find a promise by the company to insure the true owner, without which there is no proper basis for reformation. ${ }^{77}$

Some courts, especially in the South, have adopted the view that where the company knew of the limited nature of the insured's interest at the time of issuing the policy, and with such knowledge issued the insurance as upon an absolute title and thereafter collected premiums in the same amount as would be due for insurance of the entire ownership of the property, the insured should be compensated as if he held the fee title. ${ }^{78}$ This rule, which has been applied in other types of limited-interest

${ }^{70}$ See Bassett v. Farmers' and Merchants' Ins. Co., supra note 69 , at 88 , I22 N. W. at 704 .

71 Trade Ins. Co. v. Barracliff, 45 N. J. L. 543 (1883). The court stressed the fact that the policy showed a design to cover the entire ownership, from which it followed that the property insured was not necessarily the interest of the policyholder alone. The court treated the wife as a disclosed principal of the policyholder and said that the measure of recovery would be the damages accruing to whatever interests are covered by the policy so far as the insured represents those interests.

${ }^{73}$ Ritson v. Atlas Assur. Co., 272 Mass. 73, I7I N. E. 448 (1930).

${ }^{73} 26$ C. J. $\$ 459$ (1921).

"'Farmers' Mut. Fire Ins. Co. v. Harris, 50 Ga. App. 75, I77 S. E. 65 (1934); Kludt v. German Mut. Fire Ins. Co., 552 Wis. 637 , I40 N. W. 321 (1913).

${ }^{75}$ See Harrington v. Agricultural Ins. Co., 179 Minn. 5ro, 229 N. W. 792 (I930). (1934).

${ }^{70}$ See By-Fi Building and Loan Ass'n v. New York Casualty Co., I16 N. J. Eq. 265, 173 Atl. 90

${ }_{77}$ See Salomon v. North British and Mercantile Ins. Co., 215 N. X. 2I4, I09 N. E. I2I (1915).

${ }^{78}$ Western Assurance Co. v. Stoddard, 88 Ala. 606, 7 So. 379 (1889). 
cases, ${ }^{79}$ seems to be thought of as resting upon the basis of estoppel, ${ }^{80}$ although frequently no reason other than precedent is given in support of it. This doctrine is broad enough in scope to accommodate the husband-wife cases where the insurer knows the state of the title at the time of issuing the policy. Perhaps, where the insurer did not know the true condition of the title it ought to be permitted to limit the insured's recovery, if any, to the value of his own interest even in cases where a man innocently insures his wife's property. But a rule of estoppel which prevents the company from limiting recovery where it has accepted premiums with knowledge of all the facts and where there is no fraud or wagering on the part of the insured, seems to effect substantial justice without violation of desirable principles. Actually, despite the differences in the stated grounds for the decisions, the results of the husbandwife cases are consistent with this idea. This approach seems more desirable than a modification of the doctrine of indemnity along the lines suggested by $\mathrm{McClain} .^{81}$

The question of the rights of life tenant and remainderman or reversioner inter se has been exhaustively analyzed and will not be examined here. ${ }^{82}$ In the majority of jurisdictions the courts have refused to draw an analogy with the land contract cases and, in the absence of circumstances raising the inference of an agency or trust, have permitted the life tenant to retain the proceeds of the insurance. ${ }^{83} \mathrm{~A}$ minority of jurisdictions have found a fiduciary obligation on the part of the life tenant in this situation to hold the proceeds of the insurance for the benefit of the remainderman. ${ }^{84}$ The majority rule creates no difficulty under the doctrine of indemnity since these cases do not involve the question of measuring the life tenant's recovery against the insurer. The courts have not been under the same pressure that they have in the land contract cases to prevent enrichment of the insured as a result of the loss; the life tenant, unlike the vendor, bears part of the risk of loss, while the remainderman, unlike the vendee, has not typically parted with value for the property which has been destroyed or damaged. Consequently, the difference in results in the two classes of cases is understandable quite apart from the effects of equitable conversion.

\footnotetext{
${ }^{70}$ National Union Fire Ins. Co. v. Morgan, 231 Ala. 640, I66 So. 24 (1936) (tenancy in common); Farmers' Mut. Fire Ins. Co. v. Harris, 50 Ga. App. 75, I77 S. E. 65 (1934) (lease); Simmons v. Home Ins. Co., 235 Ill. App. 344 (1925) (lease); London Assur. Corporation v. Belcher, 5 S. W. 2 d 844 ('Tex. Civ. App. I928) (tenancy in common).

${ }^{80}$ Western Assur. Co. v. Stoddard, 88 Ala. 606, 6x3, 7 So. 379, 380 (1889). Opinions in these cases frequently cite decisions stating that recovery by one having an insurable interest should be permitted up to the value of the property regardless of the limitation on the insured's interest. See note 74 stipra.

${ }^{81} \mathrm{McClain}$, supra note 6, at 523: "The rule of indemnity ... has therefore, it seems, become a rule also for determining the amount of loss to be paid, with the limitation, however, that where the interest of insured is indeterminate, he shall not be denied full indemnity against possible damage from the loss." Cf. Harnett and Thornton, stipra note 6, at $\mathrm{I}_{\mathrm{I}} 76$, and Bonbright and Katz, supra notc 4, at 863-867.

${ }^{82}$ See Note, 126 A. L. R. 336 (1940). Sce Goble, op. cit. supra note 5, at 673.

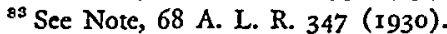

${ }^{84}$ Crisp County Lumber Co. v. Bridges, 187 Ga. 484, 200 S. E. 777 (1939). Sce Note, 126 A. L. R. 336,351 (1940).
} 
Where a lessee for years has purported fully to insure the leased property, the authorities are in conflict as to his right to recover the insurance in full where, under the terms of the lease, title to the property will vest in the lessor at the end of the term. ${ }^{85}$ The lessee for years has a clear insurable interest, ${ }^{86}$ but the considerations which have moved the courts sometimes to find an agency relationship in the husband-wife cases discussed above have generally not been present here where the parties are normally engaged in an arm's-length business transaction. Perhaps the moral hazard in permitting full recovery to a business lessee who has insured the premises up to their full value is greater here than in the case where a husband has insured his wife's property. For whatever reason, the lessee for years is more likely to be limited in recovery to an amount equal to the estimated value of his interest than is the husband who has insured his wife's property which he occupies as a homestead. ${ }^{87}$

In the absence of circumstances raising the inference of agency or trust, the lessor or lessee who is paid the proceeds of his own insurance holds them free of any claim by the other party, even though his policy covered the value of the full undivided ownership of the property. ${ }^{88}$ This rule is followed more widely than is the analogous majority rule in the case of life tenants and remaindermen. ${ }^{89}$

\section{VII}

With the assumptions set forth at the beginning of this paper in mind, the following conclusions may be drawn from the limited-interest cases:

(I) Arguments by analogy from limited-interest cases of one category to those of another should be made with caution. The considerations underlying the rules differ in the various categories.

(2) The facts of each case must be examined with unusual care lest unwarranted generalizations be drawn. The language of the particular policy, some statutory provision, or some element of agency, trust, or estoppel frequently determines the result.

(3) In only a few cases has total recovery by all owners of limited interests in excess of the amount of the loss been observed. So far the courts have not expressed particular concern over the possibility of such excess recovery.

(4) As to the rights inter se of the limited-interest owners discussed in this article, it may be concluded broadly that in the absence of any express or implied agreement, trust, or agency, the insured holds the proceeds of the insurance free of rights of the other owners, except that bailees under trust or commission policies,

${ }^{85}$ See note 58 supra.

${ }^{30}$ Wirliam R. Vanice, Handbook on the Law of Insurance 127 (2d ed. r930).

${ }^{87}$ Assuming that the husband recovers anything. See Harrington v. Agricultural Ins. Co., I79 Minn. 510, 229 N. W. 792 (x930); Harnett and Thornton, supra note 6, at Ir77.

${ }^{83}$ Miller v. Gold Beach Packing Co., 131 Ore. 302, 282 Pac. 764 (1929).

${ }^{80}$ See Note, 66 A. L. R. 864 (1930). 
vendors of land, and, in a few states, life tenants, hold the proceeds of their insurance for the benefit of their opposite parties so far as such proceeds exceed the value of their own interest in the res.

(5) The strict indemnity principle is rather faithfully adhered to except in cases where a husband fully insures his wife's property in his own name and the insurer issues the policy and collects premiums at the full rate with knowledge of the condition of the title. In that case most courts permitting recovery at all permit it in full, although the insured is often defeated by lack of insurable interest. Some states permit any limited owner having an insurable interest to recover in full in the absence of fraud where the insurer issued the policy with knowledge of the facts and collected premiums at the full-ownership rate.

(6) The temptation is strong, in dealing with limited-interest problems, to apply the technical rules of property in conjunction with the general principles of insurance in a rather narrow, formal manner. It is to be hoped that the courts will continue to approach these problems with the primary aim of achieving socially desirable results. 